\title{
HUBUNGAN DUKUNGAN KELUARGA DENGAN KEKAMBUHAN PADA PASIEN HARGA DIRI RENDAH DI RUMAH SAKIT KHUSUS JIWA SOEPRAPTO BENGKULU
}

\author{
Septi Andrianti \\ STIKES Bhakti Husada Bengkulu \\ J1. Kinibalu 8 Kebun Tebeng Bengkulu Telp (0736) 23422 \\ Email : stikesbh03@gmail.com
}

\begin{abstract}
ABSTRAK
Keluarga memiliki empat fungsi suportif, antara lain: dukungan informasional, dukungan penilaian, dukungan instrumental, dan dukungan emosional,jika dari semua dukungan ini kita dapat mengukur baik dan tidaknya dukungan keluarga kepada klien harga diri rendah. Tujuan penelitian diketahui hubungan dukungan keluarga dengan kekambuhan pada pasien harga diri rendah di Rumah Sakit Jiwa Soeprapto Bengkulu.

Desain penelitian menggunakan metode penelitian secara survey analitik dengan metode penilaian Cross Sectional,dengan jumlah sampel sebanyak 178 orang. Data dianalisis secara univariat dan bivariate dengan chi-square

Hasil penelitian menunjukkan terdapat 66 orang $(37,1 \%)$ responden memiliki dukungan keluarga kurang baik dan 70 orang $(39,3 \%)$ mengalami kekambuhan dan kembali menjalani pengobatan kurang dari 2 bulan pada pasien harga diri rendah di Rumah Sakit Jiwa Soeprapto Bengkulu tahun 2019. Hasil analisi bivariate didapatkan ada hubungan yang bermakna antara dukungan keluarga dengan kejadian kekambuhan pada pasien harga diri rendah di Rumah Sakit Jiwa Soeprapto Bengkulu

Saran peneliti hendaknya pemberian pendidikan kesehatan tentang dukungan keluarga pada penderita gangguan harga diri rendah di tingkatkan dan program home visit menjadi prioritas utama untuk mencegah kekambuhan pada penderita gangguan harga diri rendah.
\end{abstract}

Kata kunci : Harga Diri Rendah, Dukungan Keluarga

\section{RELATED BETWEEN FAMILY SUPPORT AND RECURRENCE IN LOW SELF-ESTEEM PATIENTS IN RUMAH SAKIT KHUSUS JIWA SOEPRAPTO BENGKULU}

\begin{abstract}
The family has four supportive functions, including: informational support, assessment support, instrumental support, and emotional support, if from all of this support we can measure whether or not family support for clients with low self-esteem. The purpose of the study is known to the relationship of family support with recurrence in patients with low selfesteem at Soeprapto Bengkulu Mental Hospital.

The research design used the analytical survey research method with the cross sectional assessment method, with a total sample of 178 people. Data were analyzed univariately and bivariately with chi-square
\end{abstract}


The results showed there were 66 people (37.1\%) of respondents had poor family support and 70 people (39.3\%) experienced a relapse and returned to treatment for less than 2 months in low self-esteem patients at Soeprapto Mental Hospital Bengkulu in 2019 The results of bivariate analysis found that there was a significant relationship between family support and recurrence in low self-esteem patients at Soeprapto Mental Hospital Bengkulu Suggestions researchers should provide health education about family support for patients with low self-esteem disorders are increased and the home visit program is a top priority to prevent recurrence in people with low self-esteem disorders.

\section{Keywords: Low Self-Esteem, Family Support}

\section{PENDAHULUAN}

Kesehatan

merupakan

kebutuhan yang paling mendasar bagi seluruh umat manusia baik kesehatan fisik maupun mental. Hal tersebut merupakan hak bagi setiap warga negara Indonesia. Hal ini terdapat dalam Undang-Undang Dasar 1945 Pasal 28 huruf $\mathrm{H}$ ayat (1) serta dalam Undang-Undang Republik Indonesia Nomor 36 tahun 2009 tentang Kesehatan. Pengertian kesehatan dalam Undang-Undang Republik Indonesia Nomor 36 tahun 2009 "kesehatan adalah keadaan sehat, baik secarafisik, mental, spritual maupun sosial yang memungkinkan setiap orang untuk hidup produktif secara sosial dan ekonomis". Hal tersebut menunjukkan bahwa kesehatan mendapatkan perhatian dan penanganan secara serius oleh pemerintah Indonesia (Kemenkes, 2014).

Kesehatan jiwa di dunia saat ini masih menjadi salah satu masalah kesehatan yang signifikan. Berdasarkan data dari World Health Organisasi (WHO) (2014), ada sekitar 450 juta orang di dunia yang mengalami gangguan jiwa. WHO menyatakan setidaknya ada satu dari empat orang didunia mengalami masalah mental, dan masalah gangguan kesehatan jiwa yang ada di seluruh dunia sudah menjadi masalah yang sangat serius. Sedangkan data WHO pada tahun 2016, terdapat sekitar 35 juta orang terkena depresi, 60 juta orang terkena biopolar, 47,5 orang terkena dimensia, serta 21 juta orang terkena skizofrenia. Dengan berbagai keanekaragaman seperti faktor biologis, psikologis, dan sosial, maka jumlah asus gangguan jiwa terus meningkat yang dapat berdampak pada pertambahan beban negara dan produktivitas manusia dalam jangka panjang.

Hasil Riset Kesehatan Dasar (Riskesda) tahun 2013 didapatkan hasil bahwa di Indonesia jumlah penderita gangguan jiwa saat ini adalah 236 juta orang, dengan kategori gangguan jiwa ringan $6 \%$ dari populasi dan $0,17 \%$ menderita gangguan jiwa berat, 14,3\% diantaranya mengalami pasung. Tercatat sebanyak $6 \%$ penduduk berusia 15-24 tahun mengalami gangguan jiwa. Dari 34 provinsi di Indonesia, Bengkulu merupakan peringkat ke 11 dengan jumlah gangguan jiwa sebanyak 50.608 jiwa 
dan prevalensi masalah skizofrenia pada urutan ke-2.

Meningkatnya kejadian gangguan jiwa maka perlu dilakukan upaya diantaranya program intervensi dan terapi yang implentasinya yang bukan hanya di rumah sakit tetapi dilingkungan masyarakat (community based psyciatric services) (Priyanto, 2007). Gangguan jiwa merupakan salah satu masalah kesehatan masyarakat di Indonesia. Secara umum gangguan jiwa disebabkan karena adanya tekanan psikologis baik dari luar individu maupun dari luar individu. Beberapa hal yang menjadi penyebab adalah ketidaktahuan dari keluarga dan masyarakat terhadap gangguan jiwa ini (Hawari, 2014). Gangguan jiwa merupakan adanya gangguan pada fungsi mental yang meliputi emosi, pikiran, prilaku, perasaan, motivasi, kemauan, keinginan, daya tilik diri, dan persepsi sehingga menganggu dalam proses hidup dalam masyarakat. Gangguan harga diri rendah adalah gangguan konsep diri dimana harga diri merasa gagal mencapai keinginan, perasaan tentang diri yang negatif dan merasa dirinya lebih rendah dibanding orang lain (Kusumawati,2010). Dukungan sosial sangat penting terhadap pengobatan dan kesembuhan pasien harga diri rendah. Jika tidak ada dukungan sosial penderita tidak dapat berperan sesuai harapan lingkungannya, sehingga apabila pasien dinyatakan sembuh dan kembali ke lingkungannya akan kembali dirawat dengan alasan perilakunya tidak diterima keluarga dan lingkungannya. Keadaan ini juga dipengaruhi adanya pandangan masyarakat yang tidak menguntungkan terhadap gangguan jiwa,takut, tidak peduli, tidak mau mengerti bahkan mengasingkan penderita, padahal kurangnya dukungan sosial merupakan salah satu faktor yang dapat mempengaruhi terjadinya kekambuhan pada pasien gangguan jiwa,dukungan sosial yang sangat berperan adalah dukungan keluarga (Nanda,2015).

Peran serta keluarga adalah satu usaha untuk mengurangi angka kekambuhan pada penderita gangguan jiwa seperti penderita harga diri rendah,mengingat keluarga merupakan sistem pendukung utama yang memberikan perawatan langsung setiap keadaan sehat sakit penderita (Keliat, 2007). Keluarga merupakan unit paling dekat dengan penderita,dan merupakan "perawat utama" bagi penderita. Manusia sebagai makhluk sosial tidak dapat hidup sendirian tanpa bantuan orang lain. Kebutuhan fisik (sandang, pangan, papan), kebutuhan sosial (pergaulan, pengakuan, sekolah, pekerjaan) dan kebutuhan psikis termasuk rasa ingin tahu,rasa aman, perasaan religiusitas,tidak mungkin terpenuhi tanpa bantuan orang lain. Apalagi jika orang tersebutsedang menghadapi masalah, baik ringan maupun berat.

Pada saat menghadapi masalah seseorang akan mencari dukungan sosial dari orang sekitarnya, sehingga dirinya merasa dihargai, diperhatikan dan dicintai. Keluarga memiliki empat fungsi suportif, antara lain: dukungan informasional, dukungan penilaian, dukungan instrumental, dan dukungan 
emosional,jika dari semua dukungan ini kita dapat mengukur baik dan tidaknya dukungan keluarga kepada klien harga diri rendah (Kaplan,2006).

Kuntjoro (2002), menyatakan bahwa dukungan keluarga, baik dukungan informasional, dukungan penilaian, dukungan instrumental, dan dukungan emosional akan memungkinkan seseorang memperoleh kerekatan (kedekatan) sehingga menimbulkan rasa aman bagi yang menerima. Sumber dukungan keluarga ini dapat diperoleh daripasangan atau anggota keluarga yang dekat dan memiliki hubungan yang harmonis. Bagi klien dengan gangguan jiwa dukungan ini dapat diberikan oleh anggota keluarga yang tinggal satu rumah dengan klien agar dukungan yang diberikan dapat diterima langsung klien.

Hasli penelitian Widjayanti diperoleh hasil nilai $\mathrm{p}=0,004$ dimana nilai $\mathrm{p}<0,05$ dan nilai $\mathrm{r}=0.512$ sehingga dapat ditarik kesimpulan bahwa ada hubungan atau korelasi yang kuat antara dukungan keluarga dengan harga diri klien gangguan jiwa di unit rawat jalan rs grhasia yogyakarta. Hasil penelitian dari Mujiyono (2008) dengan jumlah sampel 80 responden di dapatkan bahwa dukungan keluarga pada kategori dukungan rendah sebanyak 47 orang $(58,8 \%)$,sisanya kategori dukungan tinggi sebanyak 33 orang $(41,2 \%)$. Apabila variabel dukungan keluarga naik sebesar satu satuan, maka akan menurunkan tingkat kekambuhan sebesar 0,589 satuan dan sebaliknya apabila dukungan keluarga turun satu satuan maka angka kekambuhan meningkat 0,589 satuan. Kekambuhan penderita gangguan jiwa sangat dipengaruhi oleh peran atau dukungan keluarga terhadap penderita gangguan jiwa.

Berdasarkan data statistik medical record (rekam medik) rumah sakit khusus jiwa soeprapto provinsi bengkulu,terjadi peningkatan pasien harga diri rendah pada tahun 2016 jumlah pasien mengalami harga diri rendah 104 pasien dengan rincian 95 pasien rawat jalan dan 9 pasien rawat inap. Tahun 2017 jumlah pasien yang mengalami harga diri rendah 134 pasien dengan rincian 117 pasien rawat jalan dan 24 pasien rawat inap. Pada tahun 2018 jumlah pasien yang mengalami harga diri rendah 321 pasien dengan rincian 269 pasien rawat jalan dan 52 pasien rawat inap.

Berdasarkan survey awal di rumah sakit jiwa khusus jiwa soeprapto pada tanggal 27 april 2019 kepada 6 orang merupakan pasien ulangan atau pasien yang sebelumnya pernah dirawat. Kekambuhan yang terjadi pada 6 orang pasien berdasarkan informasi dari perawat dan pasien terjadi karena rata-rata mengalami perlakuan yang sama di keluarga mereka, yaitu sering di bedabedakan oleh anggota keluarga lain dan keluarga pasien tidak menyediakan waktu untuk menemani pasien kontrol kerumah sakit, keluarga sering lupa untuk mengingatkan pasien untuk minum obat, dan keluarga kurang memberi semangat untuk sembuh, dan biasanya karena kurangnya perhatian keluarga terhadap pasien itulah pasien sering mengalami 
kekambuhan.(Rekam medik RSJ Soeprapto,2019).

Berdasrkan latar belakang permasalah diatas, maka peneliti tertarik untuk mengadakan penelitian dengan judul "Hubungan Dukungan Keluarga Dengan Kekambuhan Pada Pasien Harga Diri Rendah Di Rumah Sakit Khusus Jiwa Soeprapto Bengkulu”.

\section{METODE PENELITIAN}

Penelitian ini digunakan metode penelitian secara survey analitik dengan metode penilaian Cross Sectional, dimana penelitian digunakan untuk meneliti hubungan dengan melakukan pengukuran variabel dilakukan sekali dalam waktu bersamaan (Notoatmodjo,2012). Variabel Independen adalah dukungan keluarga dan variabel dependen adalah kekambuhan Penelitian ini dilakukan di Rumah Sakit Jiwa Soeprapto Bengkulu pada tanggal 16 Juli - 29 Juli 2019. Populasi yang digunakan dalam penelitian ini adalah seluruh keluarga pasien harga diri rendah yang datang berkunjung di RSJ Soeprapto Bengkulu dengan jumlah pasien 352 orang. Sampel adalah sebagian yang diambil dari keseluruhan objek yang diteliti dan dianggap mewakili seluruh populasi. Cara pengambilan sampel pada penelitian ini yaitu dengan menggunakan metode "Nonprobability sampling yaitu random sampling " (Notoatmodjo, 2012). Berdasarkan perhitungan rumus besar sampel diperoleh jumlah sampel minimal sebeanyak 178 orang. Analisis secara langsung yang digunakan untuk melihat hubungan antara variabel independen (dukungan keluarga) dan variabel dependen (kekambuhan) menggunakan rumus Chi-Square dengan tingkat keyakinan 95\% atau $\alpha 0,05$. Jika $P \leq 0.05$ ada hubungan dan jika $\mathrm{P}>0,05$ tidak ada hubungan antara variabel independen dan variabel dependen.

\section{HASIL PENELITIAN}

Analisis univariat dilakukan untuk mendapatkan gambaran distribusi frekuensi variabel yang diteliti baik variabel independen maupun dependen. Varibel independen pada penelitian ini yaitu dukungan keluarga dan varibel dependen yaitu kekambuhan pasien harga diri rendah.;

Tabel 1

Distribusi Frenkuensi Dukungan Keluarga Pasien Harga Diri Rendah Di Rumah Sakit Khusus Jiwa Soeprapto Bengkulu Tahun 2019

\begin{tabular}{lll}
\hline Dukungan Keluarga & Frekuensi & Persen $(\%)$ \\
\hline Baik & 112 & 62,9 \\
Kurang & 66 & 37,1 \\
\hline Total & 178 & 100 \\
\hline
\end{tabular}

Berdasarkan tabel 1 dapat diketahui bahwa dari 178 orang pasien yang memiliki gangguan harga diri rendah terdapat hampir sebagian besar yaitu $37,1 \%$ (66 orang) memiliki dukungan keluarga yang kurang baik. 
Tabel 2

Distribusi Frenkuensi Kekambuhan Pasien Harga Diri Rendah

Di Rumah Sakit Khusus Jiwa Soeprapto Bengkulu Tahun 2019

\begin{tabular}{lll}
\hline Kekambuhan & Frekuensi & Persen $(\%)$ \\
\hline Kambuh & 70 & 39,3 \\
Tidak Kambuh & 108 & 60,7 \\
\hline Total & 178 & 100 \\
\hline
\end{tabular}

Berdasarkan tabel 2 dapat diketahui bahwa dari 178 orang terdapat hampir sebagian besar yaitu $39,3 \% \quad(70 \%)$ mengalami kekambuhan dan kembali menjalani pengobatan kurang dari 2 bulan. Analisis bivariat dilakukan untuk mengetahui hubungan antara variabel independen dan variabel dependen. Penelitian ini menggunakan analisis bivariat dilakukan untuk mengetahui hubungan dukungan keluarga dengan kekambuhan pada penderita harga diri rendah di Rumah Sakit Jiwa Soeprapto Bengkulu, dilakukan dengan menggunakan uji Chi-Square

Tabel 3

Hubungan Antara Dukungan Keluarga Dengan Kekambuhan Pada Pasien Harga Diri Rendah Di Rumah Sakit Khusus Jiwa Soeprapto Bengkulu

Tahun 2019

\begin{tabular}{lccccccc}
\hline \multirow{2}{*}{$\begin{array}{l}\text { Dukungan } \\
\text { Keluarga }\end{array}$} & \multicolumn{9}{c}{ Kambuh } & \multicolumn{2}{c}{ Tidak Kambuh } & \multirow{2}{*}{ Jumlah } & \multirow{2}{*}{$P$} \\
\cline { 2 - 7 } & $\mathrm{f}$ & $\%$ & $\mathrm{f}$ & $\%$ & $\mathrm{n}$ & $\%$ & \\
\hline Kurang & 36 & 54,5 & 30 & 45,5 & 66 & 100 & \\
$\begin{array}{l}\text { Baik } \\
\text { Baik }\end{array}$ & 34 & 30,4 & 78 & 69,6 & 112 & 100 & 0,002 \\
\hline Jumlah & 78 & 39,3 & 108 & 60,7 & 178 & 100 & \\
\hline
\end{tabular}

Berdasarkan tabel 3 diatas menunjukkan bahwa dari 66 pasien dengan dukungan keluarga kurang baik diketahui bahwa 36 orang $(54,5 \%)$ mengalami kekambuhan dan 30 orang atau $45,5 \%$ tidak mengalami kekambuhan Sedangkan dari 112 orang dengan dukungan keluarga baik diketahui bahwa 78 orang atau $69,6 \%$ tidak mengalami kekambuhan dan hanya 34 orang yang mengalami kekambuhan. Dari uji Chi-Square hasil tabel diperoleh nilai $p$ sebesar $(0,002)$ karena $p \leq 0,05$ maka $\mathrm{Ha}$ diterima artinya ada hubungan yang bermakna antara dukungan keluarga dengan kejadian kekambuhan pada pasien harga diri rendah di Rumah Sakit Jiwa Soeprapto Bengkulu tahun 2019.

\section{PEMBAHASAN \\ Dukungan Keluarga}

Berdasarkan tabel 1 dapat diketahui bahwa dari 178 orang pasien yang memiliki gangguan harga diri rendah terdapat hampir sebagian besar yaitu $37,1 \%$ (66 orang) memiliki dukungan keluarga yang kurang baik. Dukungan keluarga kurang baik diketahui Hal ini diketahui berdarkan hasil kuesioner bahwa dari 15 pertanyaan diketahui 
pada pertanyaan pertama dimana keluarga tidak memberikan kepercayaan kepada pasien dalam menghadapi masalah sebanyak 52,8\%, selain itu keluarga tidak memberikan rasa nyaman dan perasaan saling memiliki srta saling dicintai sebanyak 48,3\%. Sedangkan pada Dimensi instrumental bahwa keluarga tidak membimbing pasien untuk beraktivitas sepert biasanya sebanyak 44,9\%, selain itu terdapat $43,8 \%$ keluarga tidak menyediakan waktu untuk menemani responden kontrol ke rumah sakit. Sedangkan pada dimensi informational dimana terdapat $45,5 \%$ menyatakan bahwa keluarga tidak memberikan informasi untuk meningkatkan kesehatan.

Kurang baiknya dukungan yang didapatkan responden terhadap keluarga disebabkan oleh beberapa factor, berdasarkan hasil wawancara kepada beberapa responden diketahui bahwa gejala yang dialami disebabkan karena banyaknya masalah yang dihadapi sehingga pasien tidak mampu untuk menyelesaikan masalah dan ditambah lagi kurangnya dukungan keluarga. Kurangnya dukungan keluarga maksudnya adalah anggota keluarga terkadang tidak membawa anggota keluarganya menjalani pengobatan.

Hal ini disebabkan karena menurut pengakuan dari beberapa anggota keluarga mengatakan bahwa mereka terkadang tidak mengetahui penanganan terhadap pasien, mereka tidak mengerti keadaan dan situasi yang dialami pasien.

Dermawan (2013) menyatakan bahwa harga diri rendah adalah perasaan negatif terhadap dirinya sendiri menyebabkan kehilangan rasa percaya diri, pesimis, dan tidak berharga dikehidupan. Harga diri rendah adalah evaluasi negatif terhadap diri sendiri dan kemampuan diri disertai kurangnya perawatan diri, tidak berani menatap lawan bicara lebih banyak menunduk, berbicara lambat dan suara lemah (Keliat, 2007). Faktor yang mempengaruhi terjadinya harga diri rendah yaitu faktor predisposisi adalah suatu perubahan yang disebabkan oleh ideal diri yang tidak realistis terjadi ketergantungan dan penolakan terhadap orang lain, tidak memiliki tanggung jawab personal, megalami kegagalan berulang kali. Sedangkan faktor presipitasi adalah suatu perubahan penampilan, bentuk tubuh, kegagalan yang menyebabkan produktifitas menurun (Yosep, 2014) Dukungan keluarga menurut Francis \& Satiadarma (2004) merupakan bantuan/sokongan yang diterima salah satu anggota keluarga dari anggota keluarga lainnya dalam rangka menjalankan fungsi-fungsi yang terdapat di dalam sebuah keluarga. Keberhasilan perawatan di rumah sakit yakni pemberian obat akan menjadi sia - sia apabila tidak ditunjang oleh peran serta dukungan keluarga. Dinosetro (2008), menyatakan bahwa keluarga memiliki fungsi strategis dalam menurunkan angka kekambuhan, meningkatkan kemandirian dan taraf hidupnya serta pasien dapat beradaptasi kembali pada masyarakat dan kehidupan sosialnya.

\section{Kekambuhan Pada Penderita Harga Diri Rendah}

Berdasarkan tabel 2 dapat diketahui bahwa dari 178 orang terdapat hampir sebagian besar yaitu $39,3 \% \quad(70 \%)$ mengalami kekambuhan dan kembali menjalani pengobatan kurang dari 2 
bulan. Frekuensi kekambuhan dihitung dari seberapa sering pasien mengalami kekambuhan sehingga dirawat kembali di Rumah Sakit Jiwa dalam 2 bulan terakhir. Menurut Kelliat (2007) kekambuhan pada pasien gangguan jiwa terjadi karena timbulnya gejala yang sama seperti sebelumnya. Frekuensi kekambuhan merupakan masa atau saat-saat dimana gejala sebelumnya yang dialami klien muncul kembali dan mengakibatkan klien harus dirawat kembali. Banyak faktor yang mempengaruhi kekambuhan pasien gangguan jiwa terutama faktor dukungan keluarga dalam membantu pasien memenuhi kebutuhan maupun kemampuan dan keinginan keluarga dalam memberikan perawatan kepada anggota keluarganya yang mengalami gangguan jiwa.

Pasien rawat inap yang sudah menunjukkan perilaku yang baik setelah pengobatan dan tidak lagi menunjukkan gejala-gejala yang buruk maka dapat direkomendasikan oleh rumah sakit jiwa untuk pulang ke rumah dan menjalani rawat jalan dengan pengawasan keluarganya. Namun bagaimana jika seorang pasien yang sebelumnya mendapat perawatan yang cukup baik dan pengobatan yang sesuai dengan dosis yang diberikan oleh dokter serta diizinkan untuk menjalani rawat jalan tidak berapa lama mengalamikekambuhan dengan menunjukkan gejala-gejala seperti saat belum mendapatkan perawatan dirumah sakit jiwa.

Hal inilah yang biasa disebut dengan relaps atau kekambuhan kembali.

Kekambuhan merupakan salah satu ciri dariskizofrenia. Meskipun obat antipiskotik mampumengurangi kekambuhan hingga 30\%-40\% pada pasien yang kambuh setelah satu tahun dirawat di rumah sakit apabila mereka rutin pengobatan. Kekambuhan sangat berhubungan kuat dengan ketaatan dan ketidaktaatan pengobatan. Faktor yang paling penting sehubungan dengan perawatan kembali pasien skizofrenia adalah ketidakpatuhan pengobatan dimana pada penelitian terkontrol mereka mendapatkan hasil persentase pasien yang tidak minum obat secara nyata lebih tinggi daripada pasienpasien yang menjalani pengobatan secara rutin. Penyebab ketidakpatuhan terhadap terapi obat adalah sifat penyakit yang kronis sehingga pasien merasa bosan minum obat, berkurangnya gejala, tidak pasti tentang tujuan terapi, harga obat yang mahal, tidak mengerti tentang instruksi penggunaan obat, dosis yang tidak akurat dalam mengkonsumsi obat dan efek samping yang tidak menyenangkan

\section{Hubungan Antara Dukungan Keluarga Dengan Kekambuhan Pada Pasien Harga Diri Rendah Di Rumah Sakit Khusus Jiwa Soeprapto Bengkulu}

Berdasarkan tabel 3 diatas menunjukkan bahwa dari 70 pasien yang mengalami kekambuhan dalam waktu kurang dari 2 bulan sebanyak $51,4 \%$ atau 36 orang memiliki dukungan keluarga yang kurang baik sedangkan dari 108 orang yang tidak berobat dalam waktu kurang dari 2 bulan terdapat $72,2 \%$ memiliki dukungan keluarga yang baik. Dari uji Chi-Square hasil tabel diperoleh nilai $p$ sebesar $(0,002$ karena $p \leq 0,05$ maka Ha diterima artinya ada hubungan yang bermakna antara dukungan keluarga dengan kejadian kekambuhan 
pada pasien harga diri rendah di Rumah Sakit Jiwa Soeprapto Bengkulu tahun 2019.

Hasil peneliian ini dapat dilihat pada tabel 3 bahwa dari 70 orang penderita gangguan harga diri rendah yang mengalami kekambuhan terdapat 36 orang atau sebagian besar responden $(51,4 \%)$ dengan dukungan keluarga kurang baik. Berdasarkan hasil kuesioner diketahui bahwa dukungan keluarga kurang baik terjadi karena keluarga tidak mengerti dan memahami bagaimana cara meningkatkan harga diri pada pasien, keluarga tidak sabar sehingga keluarga mersa putus asa dan tidak dapat memberikan motivasi yang maksimal kepada pasien.

Saputra (2010), menyatakan bahwa keluarga merupakan pendukung utama dalam proses penyembuhan pasien skizofrenia untuk mencegah terjadinya kekambuhan. Dalam pemberian asuhan keperawatan, dukungan keluarga sangat penting untuk ikut berperan dalam mencegah terjadinya kekambuhan. Sikap keluarga yang tidak menerima pasien skizofrenia kembali akan membuat kekambuhan lebih cepat. Sedangkan hasil penelitian juga didapatkan dari 108 responden yang tidak mengalami kekambuhan terdapat 78 orang atau sebagian besar $(72,2 \%)$ responden mendapatkan dukungan keluarga yang baik. Berdasarkan hasil kuesioner bahwa baiknya keluarga memberikan dukungan keluarga terjadi karena keluarga memiliki pengetahuan yang baik sehingga keluarga mencoba mencari informasi tentang kondisi pasien melalui media elektronik maupun mengajukan secara mandiri pertanyaan - pertanyaan kepada petugas kesehatan tentang perkembangan dan cara mencegah kekambuhan.

Wawan (2010) menyatakan bahwa semakin banyak pengetahuan yang didapat, maka semakin besar pula dukungan yang diberikan dalam proses perawatan. Teguh (2008) mengatakan bahwa ada hubungan antara pengetahuan keluarga dengan dukungan keluarga dalam menerima kembali anggota keluarganya yang menderita penyakit kronis. Pengetahuan keluarga yang tinggi tentang penyakit dapat meningkatkan kesiapan keluarga dalam menerima kembali anggota keluarga yang menderita dirumah. Untuk itu dukungan keluarga sangat diperlukan dalam merawat anggota keluarga, karena dukungan keluarga merupakan suatu keadaan yang bermanfaat bagi indivdu yang diperoleh dari orang lain yang dapat dipercaya sehingga seseorang akan tahu bahwa ada orang lain yang memperhatikan, menghargai dan mencintainya (Setiadi, 2014).

Namun terdapat 34 orang atau hampir sebagian $\quad(48,6 \%)$ responden mendapatkan dukungan keluarga baik namun mengalami kekambuhan kurang dari 2 bulan. Adanya kekambuhan yang dialami oleh penderita dengan harga diri rendah terjadi karena keluarga berasumsi dan menganggap penderita sebagai aib bagi keluarga dan membuat mereka mengalami isolasi sosial. Oleh karena itu, penderita sering kali disembunyikan dan dikucilkan agar tidak diketahui oleh masyarakat. Hal ini justru akan memberatkan gejala yang dialami pasien, sehingga tentunya juga akan memberatkan bagi keluarga yang merawatnya (Durand \& Barlow, 2007). Kurangnya pengetahuan dari keluarga dalam hal 
merawat pasien, menjadi faktor utama dalam meningkatnya angka kekambuhan penderita. Beberapa faktor yang dapat memengaruhi pengetahuan, diantaranya: tingkat pendidikan, motivasi, pengalaman, dan persepsi (Pelling, 2008).

Terdapatnya stigma yang buruk dari masyarakat terhadap penderita gangguan jiwa, diantaranya gangguan jiwa merupakan penyakit yang sulit disembuhkan dan aib bagi keluarga (Irmansyah, 2008). Hal ini bukan hanya menimbulkan konsekuensi negatif bagi penderita, tetapi juga dapat menimbulkan persepsi yang negatif bagi keluarga sehingga muncullah sikap penolakan, sikap penyangkalan, disisihkan maupun diisolasi. Karena memiliki anggota keluarga dengan harga diri rendah bukanlah suatu hal yang mudah. Maka peran keluarga sangat penting.

Selain itu responen dengan status ekonomi yang rendah, berdasarkan hasil wawancara dan asumsi peneliti bahwa keluarga telah memberikan dukungan kepada pasien, namun keluarga mengalami kesulitan untuk melakukan pemeriksaan ruitn di Rumah Sakit Jiwa dikarenakan jarak yang jauh antara rumah dengan rumah sakit sehingga responden sering mengalami putus obat. Supriyono (2007) menyatakan bahwa kemiskinan dan jauhnya jangkauan pelayanan kesehatan menyebabkan responden tidak mampu membiayai transportasi ke pelayanan kesehatan dan ini menjadi kendala dalam melakukan pengobatan. Erlina (2010) juga menyatakan bahwa himpitan ekonomi memicu orang menjadi rentan dan terjadi berbagai peristiwa yang menyebabkan gangguan jiwa.
Dukungan keluarga yang tinggi merupakan hal penting dalam proses kesembuhan penyakit seseorang terutama dukungan keluarga. Untuk itu diharapkan keluarga harus memberikan dukungan pada pasien skizofrenia agar bisa sembuh dan tidak mengalami kekambuhan lagi. Dukungan yang dimiliki oleh seseorang dapat mencegah berkembangnya masalah akibat tekanan yang dihadapi. Seseorang dengan dukungan yang tinggi akan lebih berhasil menghadapi dan mengatasi masalahnya dibanding dengan yang tidak memiliki dukungan. Dinosetro (2008), menyatakan bahwa keluarga memiliki fungsi strategis dalam menurunkan angka kekambuhan pada penderita dan sementara besar kemungkinan untuk sembuh, meningkatkan kemandirian dan taraf hidupnya serta pasien dapat beradaptasi kembali pada masyarakat dan kehidupan sosialnya. Wahyuningrum (2013), yang berjudul hubungan dukungan keluarga dengan durasi kekambuhan pasien skizofrenia di Rumah Sakit Jiwa Daerah yaitu dukungan keluarga pada pasien skizofrenia sebesar $(86,4 \%)$. Sejalan dengan penelitian yang dilakukan Wijayanti (2010), yang berjudul hubungan dukungan sosial keluarga dengan kekambuhan pasien skizofrenia di Rumah Sakit Puri Nirmala Yogyakarta yaitu sebagian besar dukungan keluarga dengan kategori sedang sebesar (43,24\%).

Taufik (2014), kekambuhan biasanya terjadi karena hal-hal buruk yang menimpa penderita gangguan jiwa, seperti di asingkan oleh keluarganya sendiri. Hasil penelitian ini sesuai dengan hasil penelitian Wahyuningrum (2015) berjudul 
dukungan keluarga dengan durasi kekambuhan pasien skizofrenia Di Rumah Sakit Jiwa Daerah Dr. Amino Gondohutomo Semarang menyatakan bahwa dukungan keluarga berpengaruh pada kekambuhan skizofrenia.

Sebayang (2011), dengan judul penelitian hubungan dukungan sosial keluarga dengan frekuensi kekambuhan pasien skizofrenia paranoid di Poliklinik Rumah Sakit Jiwa Daerah Propsu Medan. Hasil penelitian menunjukkan bahwa ada hubungan yang signifikan antara dukungan sosial keluarga dengan frekuensi kekambuhan pasien skizofrenia paranoid $(\mathrm{P}=0,028 ; \rho$ $=0,388)$. Sejalan dengan penelitian yang dilakukan Wijayanti (2010) yang berjudul hubungan dukungan sosial keluarga dengan kekambuhan pasien skizofrenia di Rumah Sakit Jiwa Puri Nirmala Yogyakarta yaitu dengan menggunakan perhitungan korelasi kendall ada hubungan signifikan antara hubungan dukungan sosial keluarga dengan kekambuhan pasien skizofrenia di Rumah Sakit Jiwa Puri Nirmala Yogyakarta dengan nilai $\mathrm{p}=$ $(0,017)$.

Menurut peneliti, penelitian ini menunjukkan bahwa dukungan keluarga sangat penting dan utama dalam proses kesembuhan pasien gangguan harga diri rendah, keluarga harus memiliki pengetahuan yang tinggi tentang dukungan keluarga agar tidak terjadi kekambuhan yang berulang pada pasien. Untuk itu petugas kesehatan memberikan penyuluhan kepada keluarga pasien harga diri rendah tentang pentingnya dukungan keluarga.

\section{SIMPULAN DAN SARAN}

\section{Simpulan}

Hampir sebagian besar responden $(37,1 \%)$ memiliki dukungan keluarga kurang baik pada pasien harga diri rendah di Rumah Sakit Jiwa Soeprapto Bengkulu tahun 2019.

Hampir sebagian besar responden $(39,3 \%)$ mengalami kekambuhan dan kembali menjalani pengobatan kurang dari 2 bulan pada pasien harga diri rendah di Rumah Sakit Jiwa Soeprapto Bengkulu tahun 2019.

Ada hubungan yang bermakna antara dukungan keluarga dengan kejadian kekambuhan pada pasien harga diri rendah di Rumah Sakit Jiwa Soeprapto Bengkulu tahun 2019.

\section{Saran}

Saran secara praktis ditujukan kepada tenaga kesehatan (perawat) di Rumah Sakit Jiwa Khusus Soeprapto Bengkulu hendaknya melakukan pendidikan kesehatan dan melakukan komunikasi terapeutik secara terus meneurs kepada penderita gangguan harga diri rendah dan keluarga tentang pentingnya dukungan keluarga untuk mencegah kekambuhan sehingga keluarga dapat memahami bahwa pengobatan pada penderita harga diri rendah yang baik adalah perhatian dan dukungan dari keluarga yang baik.

Untuk Rumah Sakit Jiwa Khusus Soeprapto Bengkulu. Saran kepada pihak managemen Rumah Sakit Jiwa Khusus Soeprapto Bengkulu hendaknya meningkatkan program home visit kepada selırıh penderita gangguan jiwa khusus penderita harga diri rendah unt sngetahui sejauh mana penderita mendapatkan dukungan dari pihak keluarga untuk kesembuhan selain itu disarankan kepada pihak management hendaknya meningkatkan peran perawat dalam 
program pendidikan kesehatan terkait dengan harga diri rendah.

\section{DAFTAR PUSTAKA}

Darmojo,R.,Pranarka,K.,2006,Buku Ajar Ilmu Penyakit Dalam Jilid II Edisi Ketiga :Geriatri dan Gerontologi Di Indonesia, Balai Penerbit FKUI,Jakarta.

Dinosetro,2008.Hubungan antara peran keluarga dengan tingkat kekamandirian kehidupan sosial bermasyarakat pada klienSkizoprenia post perawatan di Rumah Sakit Jiwa Menur. http://core.ac.uk.11711217

Dolan,p., Canavan,J., Pinkerton, J.2006. Family Support as Reflective Practice.London : Jessica Kingsley Publisher.

Hawari. 2014. Pendekatan holistik pada gangguan jiwa. Jakarta : balai penerbit FKUI

Kaplan H.I,Sadock B.J,Grebb J.A.2006. Sinopsis Psikiatri Jilid 2. Terjemahan

Kusuma.Jakarta:Binarupa Aksara.

Keliat.2007.Proses Keperawatan Kesehatan Jiwa, Jakarta:EGC.

Kemenkes.2014.Profil Kesehatan Indonesia. Jakarta: Kementrian Kesehatan

Kuntjoro Z.2002. Masalah Kesehatan Jiwa Lansia.http://www.epsikologi.co.id .

Kuntjoro Z.2005. Dukungan Sosial Pada Lansia.http://www.epsikologi.co.id
Kusumawati ,F Dan Hartono, Y. 2010.Buku Ajar Keperawatan Jiwa. Malang: Salemba Medika

Mujiyono.2008.Hubungan Dukungan Keluarga Dengan Kekambuhan Pada Psaien Gangguan Jiwa.jurnal keperawatan jiwa

Nanda , S . 2010. Hubungan Dukungan Keluarga dengan Kekambuhan Pasien Skizofrenia di Poliklinik Rumah Sakit Jiwa Daerah Propinsi Sumatera Utara - Medan . Skripsi Keperawatan Medan : Universitas Sumatera Utara.

Priyanto.2007. Buku Ajar Keperawatan Jiwa. jakarta : salemba medika

Riskesdas .2013.Riset Kesehatan Dasar : RISKESDAS.Jakarta:Balitbang

Wahyuningrum. I.2013.Hubungan Dukungan Keluarga Dengan Durasi Kekambuhan Pasien Skizoprenia Di Rumah Sakit Jiwa Dr.Amino Gondho Utamo Semarang. Jurnal keperawatan jiwa. ejournal.stikestelogorejo.ac.id

Widjayanti,Septi .2008.Hubungan Antara Dukungan Keluarga Dengan Harga DIri Klien Gangguan Jiwa Di Unit Rawat Jalan Rumah Sakit Grahasia Yogyakarta.https://docplayer.info

WHO.2014.Investing In Mental Health. Geneva : departement of mental health and substance

Yosep. 2014. Keperawatan Jiwa, Edisi 1. Jakarta : Refika Aditama 
